\title{
Performance Evaluation of Sweet Sorghum Juice and Sugarcane Molasses for Ethanol Production
}

\author{
Mohammad Sadegh Hatamipour ${ }^{1^{*}}$, Abbas Almodares ${ }^{2}$, Mohsen Ahi ${ }^{3}$, Mohammad Ali Gorji ${ }^{2}$, \\ Qazaleh Jahanshah ${ }^{2}$
}

${ }^{1}$ University of Isfahan, College of Engineering, Chemical Engineering Department, Isfahan, Iran

${ }^{2}$ University of Isfahan, Department of Biology, College of Biology, Isfahan, Iran

${ }^{3}$ Tarbiat Modares University, Biotechnology Group, Faculty of Chemical Engineering, Tehran, Iran

"Corresponding author: e-mail: hatami@eng.ui.ac.ir

\begin{abstract}
Sweet sorghum juice and traditional ethanol substrate i.e. sugarcane molasses were used for ethanol production in this work. At the end of the fermentation process, the sweet sorghum juice yielded more ethanol with higher ethanol concentration compared to sugarcane molasses in all experiments. The sweet sorghum juice had higher cell viability at high ethanol concentrations and minimum sugar concentration at the end of the fermentation process. The ethanol concentration and yield were $8.9 \% \mathrm{w} / \mathrm{v}$ and $0.45 \mathrm{~g} / \mathrm{g}$ for sweet sorghum in $80 \mathrm{~h}$ and $6.5 \% \mathrm{w} / \mathrm{v}$ and 0.37 $\mathrm{g} / \mathrm{g}$ for sugarcane molasses in $60 \mathrm{~h}$, respectively. The findings on the physical properties of sweet sorghum juice revealed that it has better physical properties compared to sugarcane molasses, resulting to enhanced performance of sweet sorghum juice for ethanol production
\end{abstract}

Keywords: Sweet sorghum, bioethanol, sugarcane molasses, fermentation.

\section{INTRODUCTION}

Ethanol production from renewable resources has been of considerable interest in recent years. The capital investment, raw material and processing costs greatly influence the profitability of biofuel production ${ }^{1}$. The second-generation bioethanol production attracted much attention due to their availability as low cost feedstocks. Despite constant political pressure and ethical concerns about first generation biofuels, there are many challenges to develop a sustainable second-generation biofuels production process ${ }^{2}$. Since the lignocellulosic materials have a recalcitrant structure, they need pretreatment and enzymatic hydrolysis methods that may burden much process costs as well as complications of the process ${ }^{3-5}$. The fermentation of hemicellulosic hydrolysates which contains pentose sugars needs for a recombinant yeast that may not be as efficient as usual Saccharomyces cerevisiae $^{6,7}$. In Iran, ethanol is produced mostly from molasses than any other substrates. While the molasses production was facing a deficit, many ethanol production plants were built in Iran in the last decade. Deficit in raw material necessitated the search for a new substrate to act as a raw material for fuel ethanol production. Ethanol production as an alternative fuel was initiated by the fossil fuels crisis of the $1970 \mathrm{~s}^{8}$. The main factor that motivated interest in ethanol production is its suitability for blending with gasoline to reduce fossil fuel consumption, improve octane number, and promote complete combustion. This fuel is environmentally friendly relative to fossil fuels ${ }^{8}$.

Although many crops are currently under study for ethanol production, it seems that sweet sorghum has a higher potential for this purpose. Sweet sorghum is one of the most promising feedstock for ethanol production $^{9-12}$. The sweet sorghum stalk (Sorghum bicolor (L.) Moenchspp. Saccharatum) is rich in fermentable sugars that can provide raw material for ethanol production. This is a multipurpose crop used as feedstock, as well as biomass and substrate for crystalline sugar production ${ }^{12}$.
Sweet sorghum can be cultivated in both high temperate and tropical climates, while requiring only $1 / 3$ of the water needed for cane and $1 / 2$ of that required for corn. Moreover, it is tolerant to drought, flooding and saline alkalinity, 13, 14 .

Sugarcane molasses as a feedstock in the ethanol industry have some disadvantages. The high osmotic pressure of media based on cane molasses has a negative effect on ethanol fermentation. This osmotic pressure is related to the concentration of sugars and salts in the medium ${ }^{15}$. Furthermore, the high solid and calcium content of sugarcane molasses may cause serious problems in the fermentation process, especially during the distillation. Although all aspects of the sweet sorghum have not yet been fully studied, it seems that it has a good potential for commercial ethanol production ${ }^{16}$. Repeated exposure of sugar to heat in the medium during the industrial molasses production causes browning or Maillard reaction and caramelization of the product; this may reduce the fermentation efficiency and make wastewater treatment difficult ${ }^{17}, 18$. In comparison with sugarcane molasses, lower amount of sweet sorghum juice is needed for ethanol production. Conditions in an industrial ethanol production plant are usually non-sterile. This contributes to energy saving and enhances the efficiency of ethanol production through a simpler process than that of a sterile process ${ }^{19}$.

This study aims to compare the efficiency of sugarcane molasses and sweet sorghum juice as substrates for ethanol production by Saccharomyces cerevisiae under similar conditions, and evaluate the effects of initial sugar concentration, heat treatment, fermentation kinetics and physical properties on the ethanol yield.

\section{MATERIAL AND METHODS}

\section{Sweet sorghum juice and microorganisms}

Sugarcane molasses was provided by Sugar Cane and By Products Development Co., Ahvaz, Iran. Sweet sorghum was provided by the research farm of the University of 
Isfahan, Iran. The leaves and panicles of the fresh crops were stripped manually from the stalks. Crushed stalks then was fed to a roller mill for fresh juice production with an approximate ${ }^{\circ}$ Brix of $15-20$. The fresh juice was concentrated to $62^{\circ} \mathrm{Brix}$ by heating and stored at ambient temperature. Fermentation carried out by use of the commercial dry yeast strain of Saccharomyces cerevisiae (Klarmayeh, Iran).

\section{Analytical methods}

The solid content of the juice is expressed in ${ }^{\circ} \mathrm{Brix}$ determined by a portable refractometer (0-30 $\left.{ }^{\circ} \mathrm{Brix}\right)$. The juice centrifuged at $3000 \mathrm{rpm}$ for $5 \mathrm{~min}$, and the supernatant was kept at $-20^{\circ} \mathrm{C}$ in a freezer for sugar and alcohol amount determination. The total reducing sugar of the medium was determined using the DNS (3.5 dinitrosalicylic acid) method after sugar hydrolysis with $6 \mathrm{M} \mathrm{HCl}$ for $20 \mathrm{~min}$ at $95^{\circ} \mathrm{C}$. The medium then was neutralized with $6 \mathrm{M} \mathrm{NaOH}^{\mathbf{2 0}, 21}$.

Ethanol analysis was carried out by use of sulfochromic acid reagent. For each ethanol analysis, the sulfochromic acid reagent was prepared by the reaction between 20 $\mathrm{mL}$ of $43 \mathrm{~g} / \mathrm{L}$ potassium dichromate (Merck) and 10 $\mathrm{mL}$ of an extra pure sulfuric acid (Merck) solution. A boiling flask with a side tube was used for distillation of fermentation medium. The side tube of the boiling flask was placed in a bulbed tube (to avoid overflow) containing the sulfochromic acid reagent. As the boiling flask heated, the distillate was continuously transferred to the sulfochromic acid reagent in the bulbed tube. The final fermentation media was heated to a point where $3 / 4$ of the initial volume vaporized (to ensure complete stripping of ethanol and prevent vaporization of other organic volatiles). The ethanol was measured by reading the optical density of sulfochromic acid reagent at 574 $\mathrm{nm}$ after distillation ${ }^{22}$. The ethanol standard curve was prepared using the pure ethanol (Merck), to determine the ethanol content of the supernatant. The ethanol yield $\left(\mathrm{Y}_{\mathrm{p} / \mathrm{s}}\right)$ is expressed as $g$ ethanol produced/ $g$ sugar consumed $(\mathrm{g} / \mathrm{g})$.

\section{Inoculum preparation}

The sweet sorghum juice and sugarcane molasses with a ${ }^{\circ}$ Brix of 6 were pasteurized at $60^{\circ} \mathrm{C}$ for $30 \mathrm{~min}$ and then were cooled to ambient temperature to prepare an inoculum. A pre-determined amount of commercial dry yeast was added to the medium and was cultivated for $10 \mathrm{~h}$. An adequate amount of inoculum $\left(10^{7} \mathrm{CFU} / \mathrm{mL}\right)$ was added on the fermentation medium at the beginning of the fermentation.

\section{Fermentation conditions}

Fermentation was conducted at $30^{\circ} \mathrm{C}$ and $120 \mathrm{rpm}$ using $250 \mathrm{~mL}$ shaking flasks. For all experiments, fermentation was performed $35 \mathrm{~h}$ after the inoculation, unless other conditions are stated. All experiments were carried out in duplicate.

\section{The correlation between total sugar content and ${ }^{\circ} \mathrm{Brix}$}

In order to use both the sugarcane molasses and sweet sorghum as a feed in the fermentation process, it is necessary to determine their sugar content as a function of ${ }^{\circ}$ Brix. The total reducing sugar for both sweet sorghum juice and sugarcane molasses has a linear relationship with ${ }^{\circ}$ Brix (see Fig. 1). The above relationships are correlated by Equations (1) and (2).

$\mathrm{y}=0.9557 \mathrm{x}+3.2479$ for sweet sorghum juice

$\mathrm{y}=1.3897 \mathrm{x}-4.5137$ for sugarcane molasses

where, $y$ is the percentage $(\mathrm{w} / \mathrm{v})$ of total reducing sugar, and $x$ is the ${ }^{\circ}$ Brix. The correlation coefficient $\left(\mathrm{R}^{2}\right)$ is 0.987 for sweet sorghum concentrate and 0.990 for sugarcane molasses.

\section{Heat treatment}

To evaluate the effect of heat treatment on the fermentation performance of sweet sorghum juice, four experiments were conducted with different conditions. These heating treatments were aimed to reduce microbial flora. Since the $\mathrm{pH}$ and temperature may influence the precipitation in sugarcane molasses ${ }^{\mathbf{2 3}}$, it may influence the fermentation performance. Most ethanol plants tend to reduce the $\mathrm{pH}<4.5$ to control the contamination ${ }^{\mathbf{1 5}}$. The dilution may be done on $\mathrm{pH} 4.2$, then the heat treatments performed at $60^{\circ} \mathrm{C}^{24}$. To examine the effect of heat treatments on the fermentation performance at the optimum $\mathrm{pH}$ of $S$. cerevisiae $(\mathrm{pH} 5.5)^{\mathbf{2 5}}$, the following experiments were carried out:

1 - Raw sweet sorghum juice without any manipulation

2 - Raw sweet sorghum heated at $60^{\circ} \mathrm{C}$ for $30 \mathrm{~min}$ without any $\mathrm{pH}$ manipulation

3 - Raw sweet sorghum adjusted to $\mathrm{pH} 4.2$ and heated at $60^{\circ} \mathrm{C}$ for $30 \mathrm{~min}$, after heating $\mathrm{pH}$ was re-adjusted to $\mathrm{pH} 5.5$

4 - Raw sweet sorghum sterilized at $121^{\circ} \mathrm{C}$ for $10 \mathrm{~min}$ in autoclave

\section{Determining physical properties}

Physical properties such as ${ }^{\circ} \mathrm{Brix}, \mathrm{pH}$, total solids, suspended solids, color, ash, and viable cells were determined according to Praj industries analytical methods ${ }^{\mathbf{2 0}}$.

\section{RESULTS AND DISCUSSION}

\section{The effects of initial sugar concentration on fermentation}

Sugar consumption and ethanol production took place during the fermentation of sweet sorghum juice or sugarcane molasses at the initial ${ }^{\circ}$ Brix of 15,22 , and 30 using $S$. cerevisiae. According to Table 1, the ethanol concentration and fermentation yield of the sweet sorghum juice at $15{ }^{\circ}$ Brix were $5.38 \% \mathrm{w} / \mathrm{v}$ and $0.39 \mathrm{~g} / \mathrm{g}$, respectively, which are higher than those of the sugarcane molasses $(3.63 \% \mathrm{w} / \mathrm{v}$ and $0.26 \mathrm{~g} / \mathrm{g})$. The highest fermentation performance occurred at $22{ }^{\circ} \mathrm{Brix}$ for the sweet sorghum juice and the sugarcane molasses (Table 1). Figures 2 shows that the highest ethanol yields were at 30 and $22{ }^{\circ}$ Brix for sugarcane molasses and sweet sorghum, respectively. However, Figure 3 show that 22 ${ }^{\circ}$ Brix is the most appropriate initial sugar concentration for both substrates. Wu et al. $^{\mathbf{2 6}}$ reported that $20 \%$ is the upper limit for the initial sugar and that result is consistent with our finding. The ethanol concentration and the fermentation yield for sweet sorghum at a ${ }^{\circ}$ Brix of 30 decreased significantly. Although the sugarcane molasses showed a small increase in fermentation yield in ${ }^{\circ}$ Brix of 30 , its ethanol concentration decreases. A 
Table 1. Effect of different initial sugar concentration for sweet sorghum and sugarcane molasses

\begin{tabular}{|c|c|c|c|c|c|c|}
\hline Run & Time [h] & ${ }^{\circ}$ Brix & \%Total sugar & $\mathrm{pH}$ & $\%$ ethanol & $\mathrm{Y}_{\mathrm{p} / \mathrm{s}}$ \\
\hline \multicolumn{7}{|c|}{ Sweet sorghum juice } \\
\hline 1 & 0 & 15 & 15.2 & 5.84 & 0 & \multirow{2}{*}{0.39} \\
\hline & 35 & 6.2 & 1.32 & 4.43 & 5.38 & \\
\hline 2 & 0 & 22 & 23.26 & 5.7 & 0 & \multirow[b]{2}{*}{0.45} \\
\hline & 35 & 10.6 & 6.8 & 4.64 & 7.38 & \\
\hline 3 & 0 & 30 & 33 & 5.53 & 0 & \multirow{2}{*}{0.17} \\
\hline & 35 & 25.4 & 15.06 & 5.04 & 2.99 & \\
\hline \multicolumn{7}{|c|}{ Sugarcane molasses } \\
\hline 1 & 0 & 15 & 17.86 & 5.51 & 0 & \multirow{2}{*}{0.26} \\
\hline & 35 & 9.2 & 4.16 & 5.3 & 3.63 & \\
\hline 2 & 0 & 22 & 26.5 & 5.46 & 0 & \multirow{2}{*}{0.30} \\
\hline & 35 & 13.8 & 8.1 & 5.3 & 5.52 & \\
\hline 3 & 0 & 30 & 36.48 & 5.45 & 0 & \multirow{2}{*}{0.33} \\
\hline & 35 & 21.8 & 20.71 & 5.35 & 5.24 & \\
\hline
\end{tabular}

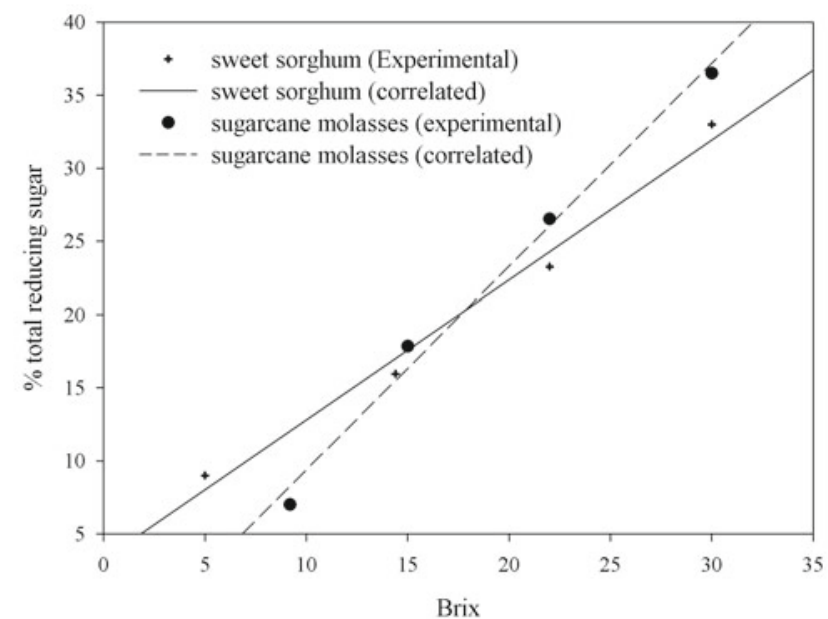

Figure 1. Correlation between total sugar percentage and ${ }^{\circ}$ Brix for sweet sorghum juice and sugarcane molasses

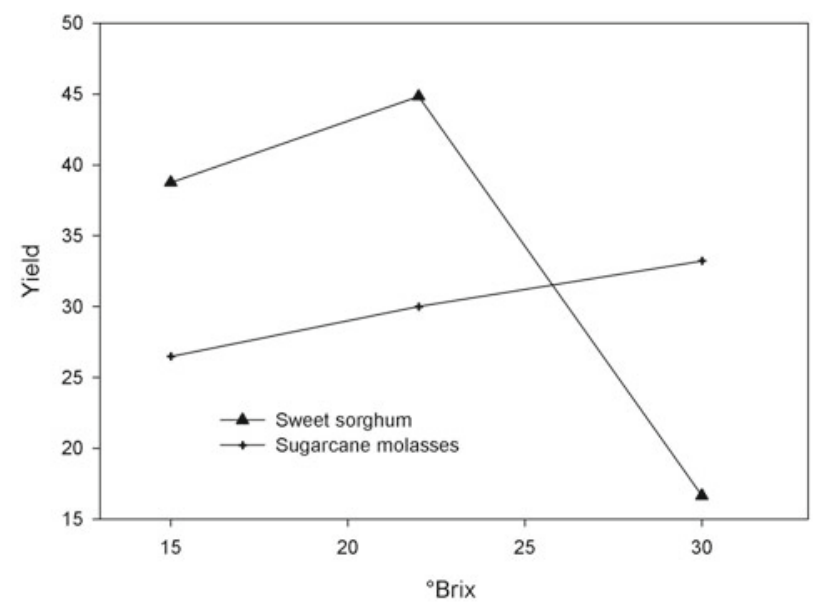

Figure 2. Comparison of yield of fermentation for sweet sorghum and sugarcane molasses

decrease in ethanol concentration in higher initial sugar concentrations may be attributed to the inhibition of yeast growth and loss of yeast cell viability due to alcoholic and osmotic stresses at higher osmotic pressures ${ }^{27,28}$.

\section{Effects of heat treatment on ethanol yield}

Sweet sorghum and sugarcane molasses are rich with different minerals. Exposing the substrate to sterilization and heating treatment may have positive impacts on the ethanol yield. In industrial ethanol production

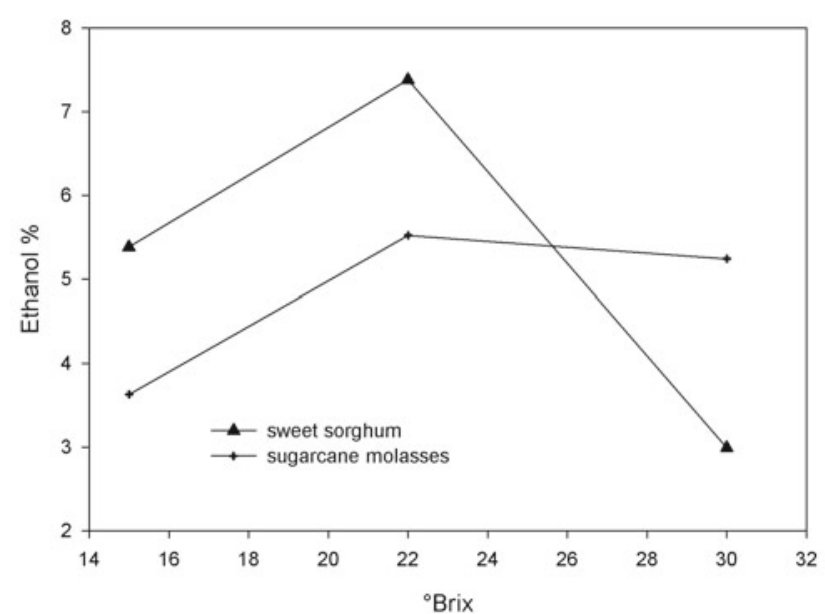

Figure 3. Comparison of final ethanol concentration for sweet sorghum and sugarcane molasses fermentation

from sugarcane molasses, it is common to perform pretreatments on the substrates in order to reduce the suspended solids and un-dissolved compounds that may cause precipitation in the subsequent stages of the fermentation process. The main problem in this area is the presence of calcium compounds mostly derived from the lime added at the sugar mills ${ }^{\mathbf{1 5}}$. Some industrial data gathered from local ethanol plants describe the effect of heat treatment on the fermentation yield of sugarcane molasses. To evaluate the heating effect on ethanol yield from the sweet sorghum, four sets of experiments were conducted (Table 2). Results showed that the fermentation in non-sterile conditions (treatment 1 ) is similar to the ones under sterile conditions (treatments 2 and 4). In treatment 3, the sweet sorghum had the lowest ethanol production that, it may be justified that the precipitation of minerals had a negative effect on ethanol fermentation. Domestic Iranian ethanol plants have reported similar results for the sugarcane molasses fermentation $^{29}$.

Table 2. Effect of pasteurization and heat treatment on sweet sorghum fermentation (see text)

\begin{tabular}{|l|c|c|c|c|c|}
\hline $\begin{array}{l}\text { Type of } \\
\text { treatment }\end{array}$ & $\begin{array}{c}\mathrm{pH} \\
\text { manipula- } \\
\text { tion }\end{array}$ & $\mathrm{pH}_{\mathrm{i}}$ & $\mathrm{pH}_{\mathrm{f}}$ & ${ }^{\circ}$ Brix & $\begin{array}{c}\% \\
\text { alcohol }\end{array}$ \\
\hline 1 & No & 5.82 & 4.67 & 9.1 & 7.30 \\
\hline 2 & No & 5.72 & 4.65 & 9.2 & 7.32 \\
\hline 3 & Yes & 5.5 & 4.73 & 16.2 & 2.65 \\
\hline 4 & No & 5.65 & 4.63 & 9 & 7.23 \\
\hline
\end{tabular}




\section{Evaluation of the fermentation kinetics}

Figure 4 shows the time courses of ${ }^{\circ}$ Brix, $\mathrm{pH}$, wet cell mass, \% total sugar and ethanol (w/v) in the sweet sorghum fermentation. After $96 \mathrm{~h}$ fermentation, the final ethanol concentration and the ethanol yields were $8.9 \% \mathrm{w} / \mathrm{v}$ and $0.45 \mathrm{~g} / \mathrm{g}$, respectively. As indicated in Figure 4 , the fermentation of sweet sorghum juice was stopped after $80 \mathrm{~h}$ where ${ }^{\circ}$ Brix and total sugars remained constant. Figure 5 shows the changes in ${ }^{\circ} \mathrm{Brix}, \mathrm{pH}$, wet cell mass, $\%$ total sugar and ethanol (w/v) during the sugarcane molasses fermentation. The final ethanol concentration was $6.5 \%$ (ethanol yield $0.37 \mathrm{~g} / \mathrm{g}$ ) after $72 \mathrm{~h}$ fermentation of sugarcane molasses. By comparison with the fermentation kinetics of sweet sorghum (Figure 4), it may be concluded that sweet sorghum has higher ethanol production as well as ethanol yield $(8.9 \% \mathrm{w} / \mathrm{v}$ and $0.45 \mathrm{~g} / \mathrm{g})$ than that of the sugarcane molasses $(6.5 \% \mathrm{w} / \mathrm{v}$ and $0.37 \mathrm{~g} / \mathrm{g})$. In addition, to achieve a constant total sugar and lower ${ }^{\circ}$ Brix it is necessary to have about $80 \mathrm{~h}$ fermentation for sweet sorghum instead of $60 \mathrm{~h}$ for the sugarcane molasses. At the end of the fermentation, sweet sorghum consumed all the sugars and had a higher ethanol concentration and ethanol yield than that of the sugarcane molasses. Ethanol concentration and yield obtained using sweet sorghum juice were $8.9 \%(\mathrm{w} / \mathrm{v})$ and $0.45 \mathrm{~g} / \mathrm{g}$ sugar, respectively, while ethanol concentration and yield obtained using sugarcane molasses were $6.5 \%(\mathrm{w} / \mathrm{v})$ and $0.37 \mathrm{~g} / \mathrm{g}$ sugar, respectively. Results showed that for both substrates at the beginning of the fermentation there is a decrease in $\mathrm{pH}$, while at the end of the fermentation, when all

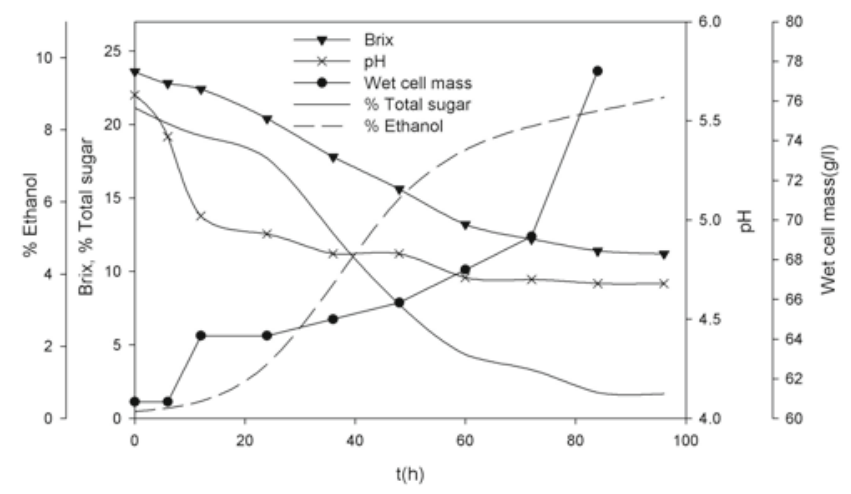

Figure 4. Relationship between ${ }^{\circ} \mathrm{Brix}$, $\mathrm{pH}$, wet cell mass, total sugar and ethanol $(\% \mathrm{w} / \mathrm{v})$ versus time in batch cultivation using sweet sorghum as substrate

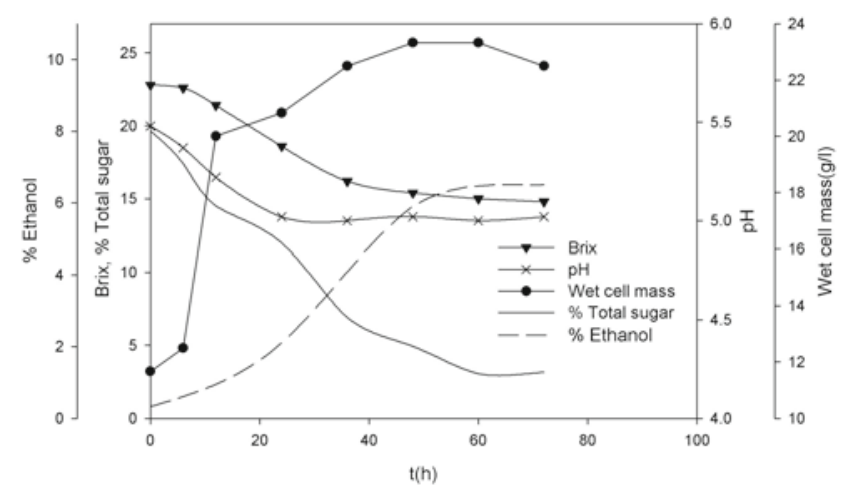

Figure 5. Relationship between ${ }^{\circ} \mathrm{Brix}, \mathrm{pH}$, wet cell mass, total sugar and ethanol $(\% \mathrm{w} / \mathrm{v})$ versus time in batch cultivation using sugarcane molasses as substrate the reducing sugars of the medium depleted, the $\mathrm{pH}$ remains almost constant. Figures 4 and 5 show that the wet cell mass for the fermentation of the sweet sorghum juice is higher than that for the sugarcane molasses. This difference is attributed to the existence of high amount of suspended solids in the sweet sorghum juice. While the yeast concentration showed an increasing trend at the end of the fermentation of the sweet sorghum juice, the yeast concentration reduced effectively in the sugarcane molasses fermentation. The loss of yeast cell viability may be due to the toxic materials produced during the fermentation. High viability of the yeast cells at the end of the fermentation is important since it could be used in a recycle system. Recycle systems are gaining interest because they can reduce the fermentation time and the cost of inoculum development.

\section{Comparison between the physical properties of the substrates}

Physical properties of each substrate definitely have significant effects on the design and sustainability, operational cost, yield, and productivity of a given process in any field.

In order to store a sugar-containing feedstock, the given substrate should be concentrated in such a manner as to avoid microbial spoilage. In this study, sweet sorghum juice was concentrated to ${ }^{\circ}$ Brix 62 in order to avoid microbial contamination. Below this ${ }^{\circ}$ Brix, molds could grow for a short period.

The storage of feedstock depends on its $\mathrm{pH}$ value. Lower $\mathrm{pH}$ values reduce the contamination. Table 3 shows that both substrates have a similar low $\mathrm{pH}$; hence, no serious contamination problems arise during the storage of either substrate.

Total solid content is another important parameter in the fermentation process. The total solid content of the feedstock directly affects the recycling process of the effluent and the evaporation. When the total solid increases, the yeast activity decreases ${ }^{\mathbf{2 0}}$; the liquid pumping encounters serious problems and the precipitation of solids may occur in storage tanks. The prepared sweet sorghum juice in this study had a lower total solid content than sugarcane molasses.

Since the suspended solids are capable of causing problems during the distillation, they should be eliminated in a precipitation unit. The materials produced from thermal destruction of reducing sugars during the processing may cause a color change in the molasses. The color change in feedstock is due to the caramelization of the sugars that are inhibitors for the yeast performance. The color of the sweet sorghum is lighter in comparison with that of the sugarcane molasses (see Table 3).

Viable cells, usually in the form of molds, may exist in the feedstock, but they are inactive due to high osmotic pressure. The viable cells for the sweet sorghum juice as a feedstock cannot cause any serious problem, and this amount of viable cells is in the acceptable range. In this study, the sweet sorghum juice contained more viable cells than sugarcane molasses, because former's ${ }^{\circ}$ Brix was lower than that of the latter. 
Table 3. Physical properties of sugarcane molasses and sweet sorghum

\begin{tabular}{|c|c|c|}
\hline Property & Sorghum & Molasses \\
\hline${ }^{\circ}$ Brix & 62 & 85 \\
\hline $\mathrm{pH}$ & 5.2 & 5.34 \\
\hline Total solid & 475.5 & 687 \\
\hline Dry suspended solid & 27 & 18 \\
\hline Dried suspended solid in acid media $[\mathrm{pH}=4.5]$ & 6 & 15.76 \\
\hline $\begin{array}{l}\text { Dried suspended solid in } \\
\text { boiled \& acid media [pH }=4.5]\end{array}$ & 10.5 & 23.46 \\
\hline OD for caramel [375 nm] & 0.048 & 0.443 \\
\hline Ash & 7.12 & 12.7 \\
\hline Viable cells [CFU/g] & 4500 & 0 \\
\hline
\end{tabular}

\section{CONCLUSIONS}

The sweet sorghum juice used in this project had higher ethanol yield than that of the sugarcane molasses in all experiments. Lower cell viability at the end of the fermentation process and lower ethanol yield of the sugar cane molasses attributed to the toxins that produced in the repeated heating of the sugarcane syrup. These materials have inhibitory effects on the yeast cells. Sugarcane molasses have higher amount of impurities than the sweet sorghum, which may cause several problems in ethanol production; therefore, for practical purposes, the final cost of the substrate production as well as ethanol yield and ethanol concentration determine the appropriate type of substrate. Due to the higher cell viability of the sweet sorghum juice at high ethanol concentration, its minimum sugar concentration at the end of the fermentation and its better physical properties in comparison with those of the sugarcane molasses, the sweet sorghum juice was found to be preferable to sugarcane molasses.

\section{ACKNOWLEDGMENT}

This research was supported by Chancellor of Research, University of Isfahan, Iran under grant no. 860716.

\section{LITERATURE CITED}

1. Chuck-Hernandez, C., Perez-Carrillo, E. \& Serna-Saldivar, S.O. (2009). Production of bioethanol from steam-flaked sorghum and maize. J. Cereal Sci. 50(1), 131-137. DOI: 10.1016/j. jcs.2009.04.004.

2. Yamamoto, M., Iakovlev, M., Bankar, S., Tunc, M.S. \& van Heiningen, A. (2014). Enzymatic hydrolysis of hardwood and softwood harvest residue fibers released by sulfur dioxideethanol-water fractionation. Bioresour. Technol. 167, 530-538. DOI: 10.1016/j.biortech.2014.06.054.

3. Cotana, F., Cavalaglio, G., Gelosia, M., Coccia, V., Petrozzi, A. \& Nicolini, A. (2014). Effect of Double-Step Steam Explosion Pretreatment in Bioethanol Production from Softwood. Appl. Biochem. Biotechnol. 174(1), 156-167. DOI: 10.1007/ s12010-014-1046-4.

4. Biswas, R., Uellendahl, H. \& Ahring, B.K. (2014). Wet explosion pretreatment of sugarcane bagasse for enhanced enzymatic hydrolysis. Biomass Bioenerg. 61, 104-113. DOI: 10.1016/j.biombioe.2013.11.027.

5. Ahi, M., Azin, M., Shojaosadati, S.A., Vasheghani-Farahani, E. \& Nosrati, M. (2013). Optimization of Sugarcane Bagasse Hydrolysis by Microwave-Assisted Pretreatment for Bioethanol Production. Chem. Eng. Technol. 36(11), 1997-2005. DOI: 10.1002/ceat.201300233.

6. Zhu, J.-Q., Qin, L., Li, B.-Z. \& Yuan, Y.-J. (2014). Simultaneous saccharification and co-fermentation of aqueous ammonia pretreated corn stover with an engineered Saccharo- myces cerevisiae SyBE005. Bioresour. Technol. 169, 9-18. DOI: 10.1016/j.biortech.2014.06.085.

7. Sasaki, K., Tsuge, Y., Sasaki, D., Hasunuma, T., Sakamoto, T., Sakihama, Y., Ogino, C. \& Kondo, A. (2014). Optimized membrane process to increase hemicellulosic ethanol production from pretreated rice straw by recombinant xylose-fermenting Saccharomyces cerevisiae. Bioresour. Technol. 169, 380-386. DOI: 10.1016/j.biortech.2014.06.101.

8. Balat, M. \& Balat, H. (2009). Recent trends in global production and utilization of bio-ethanol fuel. Appl. Energy 86(11), 2273-2282. DOI: 10.1016/j.apenergy.2009.03.015.

9. Zhang, C., Xie, G., Li, S., Ge, L. \& He, T. (2010). The productive potentials of sweet sorghum ethanol in China. Appl. Energy 87(7), 2360-2368. DOI: 10.1016/j.apenergy.2009.12.017.

10. Zhou, A. \& Thomson, E. (2009). The development of biofuels in Asia. Appl. Energy 86 (Supplement 1), S11-S20. DOI: $10.1016 /$ j.apenergy.2009.04.028.

11. Yan, J. \& Lin, T. (2009). Biofuels in Asia. Appl. Energy 86(Supplement 1), S1-S10. DOI: 10.1016/j.apenergy.2009.07.004.

12. Gnansounou, E., Dauriat, A. \& Wyman, C.E. (2005). Refining sweet sorghum to ethanol and sugar: economic trade-offs in the context of North China. Bioresour. Technol. 96(9), 985-1002. DOI: 10.1016/j.biortech.2004.09.015.

13. Almodares, A. \& Hadi, M.R. (2009). Production of bioethanol from sweet sorghum: A review. Afr. J. Agr. Res. 4(9), 772-780.

14. Sánchez, Ó.J. \& Cardona, C.A. (2008). Trends in biotechnological production of fuel ethanol from different feedstocks. Bioresour. Technol. 99(13), 5270-5295. DOI: 10.1016/j. biortech.2007.11.013.

15. Jacques, K.A., Lyons, T.P. \& Kelsall, D.R. (1999). The alcohol textbook : a reference for the beverage, fuel and industrial alcohol industries (3rd ed). Nottingham: Nottingham University Press.

16. Cutz, L. \& Santana, D. (2014). Techno-economic analysis of integrating sweet sorghum into sugar mills: The Central American case. Biomass Bioenerg. 68, 195-214. DOI: 10.1016/j. biombioe.2014.06.011.

17. Naik, N., Jagadeesh, K. \& Alagawadi, A. (2008). Microbial decolorization of spentwash: a review. Indian J. Microbiol. 48(1), 41-48. DOI: 10.1007/s12088-008-0005-6.

18. Sangave, P.C., Gogate, P.R. \& Pandit, A.B. (2007). Combination of ozonation with conventional aerobic oxidation for distillery wastewater treatment. Chemosphere 68(1), 32-41. DOI: 10.1016/j.chemosphere.2006.12.053.

19. Tao, F., Miao, J.Y., Shi, G.Y. \& Zhang, K.C. (2005). Ethanol fermentation by an acid-tolerant Zymomonas mobilis under non-sterilized condition. Process Biochem. 40(1), 183-187. DOI: $10.1016 /$ j.procbio.2003.11.054.

20. Praj Industries (2004). Analytical Methods for Cane Feedstock Based Fermentation and Distillation Process 4th ed. Pune, India: Praj Matrix - The Innovation Center.

21. Roukas, T. (1996). Ethanol production from non-sterilized beet molasses by free and immobilized Saccharomyces cerevisiae cells using fed-batch culture. J. Food Eng. 27(1), 87-96. DOI: 10.1016/0260-8774(94)00076-L. 
22. Mobini-Dehkordi, M., Nahvi, I., Zarkesh-Esfahani, H., Ghaedi, K., Tavassoli, M. \& Akada, R. (2008). Isolation of a novel mutant strain of Saccharomyces cerevisiae by an ethyl methane sulfonate-induced mutagenesis approach as a high producer of bioethanol. J. Biosci. Bioeng. 105(4), 403-408. DOI: $10.1263 /$ jbb.105.403.

23. Bernhardt, H.W. (1998). Centrifugal clarification of molasses. In 72th Annual Congress of the South African Sugar Technologists' Association (Proc S Afr Sug Technol Ass) (pp. 278-284). South Africa: South African Sugar Technologists' Association.

24. Inamdar, S. (1994). Effect of pretreatment of molasses and posttreatment of fermented broth in industrial production of ethanol. Appl. Biochem. Biotechnol. 45-46(1), 181-187. DOI: 10.1007/BF02941797.

25. Win, S.S., Impoolsup, A. \& Noomhorm, A. (1996). Growth kinetics of Saccharomyces cerevisiae in batch and fedbatch cultivation using sugarcane molasses and glucose syrup from cassava starch. J. Ind. Microbiol. 16(2), 117-123. DOI: 10.1007/BF01570071.

26. Wu, X., Staggenborg, S., Propheter, J.L., Rooney, W.L., Yu, J. \& Wang, D. (2010). Features of sweet sorghum juice and their performance in ethanol fermentation. Ind. Crop. Prod. 31(1), 164-170. DOI: 10.1016/j.indcrop.2009.10.006.

27. Laluce, C., Palmieri, M.C. \& Dacruz, R.C.L. (1991). Growth and fermentation characteristics of new selected strains of Saccharomyces at high-temperatures and high cell densities. Biotechnol. Bioeng. 37(6), 528-536. DOI: 10.1002/bit.260370606.

28. Pratt, P.L., Bryce, J.H. \& Stewart, G.G. (2003). The effects of osmotic pressure and ethanol on yeast viability and morphology. J. Inst. Brew. 109(3), 218-228. DOI: 10.1002/j.20500416.2003.tb00162.x.

29. Miahipour, A., Bonakdarpour, B. \& Bahrami, A. (2004). Considerations on the sugarcane molasses clarification for the ethanol production process (In Persian). In 9th Iranian National Conference of Chemical Engineering (23-25 November 2004) (pp. 1560-1568). Tehran, Iran: Iran University of Science \& Technology. 